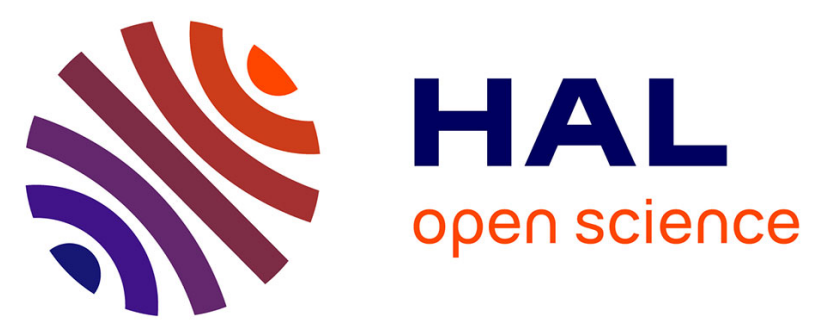

\title{
Production of a methyl ester from the microalgae Nannochloropsis grown in raceways on the French west coast
}

Béatrice Perrier, Christelle Crampon, Olivier Guézet, Coralie Simon, François Maire, Olivier Lépine, Jeremy Pruvost, Paul Lozano, Olivier Bernard, Elisabeth Badens

\section{To cite this version:}

Béatrice Perrier, Christelle Crampon, Olivier Guézet, Coralie Simon, François Maire, et al.. Production of a methyl ester from the microalgae Nannochloropsis grown in raceways on the French west coast. Fuel, 2015, 153, pp.640-649. 10.1016/j.fuel.2015.03.011 . hal-01247077

\section{HAL Id: hal-01247077 \\ https://hal.inria.fr/hal-01247077}

Submitted on 17 Apr 2020

HAL is a multi-disciplinary open access archive for the deposit and dissemination of scientific research documents, whether they are published or not. The documents may come from teaching and research institutions in France or abroad, or from public or private research centers.
L'archive ouverte pluridisciplinaire HAL, est destinée au dépôt et à la diffusion de documents scientifiques de niveau recherche, publiés ou non, émanant des établissements d'enseignement et de recherche français ou étrangers, des laboratoires publics ou privés. 


\title{
Production of a methyl ester from the microalgae Nannochloropsis grown in raceways on the French west coast
}

\author{
Béatrice Perrier $^{\mathrm{a}, *}$, Christelle Crampon ${ }^{\mathrm{b}}$, Olivier Guézet ${ }^{\mathrm{a}}$, Coralie Simon ${ }^{\mathrm{a}}$, François Maire ${ }^{\mathrm{a}}$, \\ Olivier Lépine ${ }^{c}$, Jérémy Pruvost ${ }^{c}$, Paul Lozano ${ }^{\mathrm{d}}$, Olivier Bernard ${ }^{\mathrm{e}}$, Elisabeth Badens ${ }^{\mathrm{b}}$ \\ ${ }^{a}$ PSA Peugeot Citroën, Direction Recherche E' Développement, 18 rue des Fauvelles, 92256 La Garenne-Colombes, France \\ ${ }^{\mathrm{b}}$ Aix Marseille Université, CNRS, Centrale Marseille, M2P2 UMR 7340, 13451 Marseille, France \\ 'AlgoSource/Alpha Biotech, 37 bd de l'Université, BP 406, 44602 Saint-Nazaire, France \\ ${ }^{\mathrm{d}}$ CIRAD, UMR 116 ISEM, 73 rue J.F. Breton, 34098 Montpellier Cedex 5, France \\ ${ }^{\mathrm{e}}$ BIOCORE, INRIA Sophia Antipolis, BP 93, 06902 Sophia Antipolis Cedex, France
}

\section{H I G H L I G H T S}

- Microalgae appeared to be highly sensitive to climatic conditions.

- With the high level of free fatty acids in lipids transesterification was complex.

- Poor oxidation stability in the final fuel was detrimental to engine injectors.

- Storage must be controlled to avoid the degradation of biomass over time.

- This energy intensive pathway could benefit from the use of renewable electricity.
G R A P H I C A L A B S T R A C T

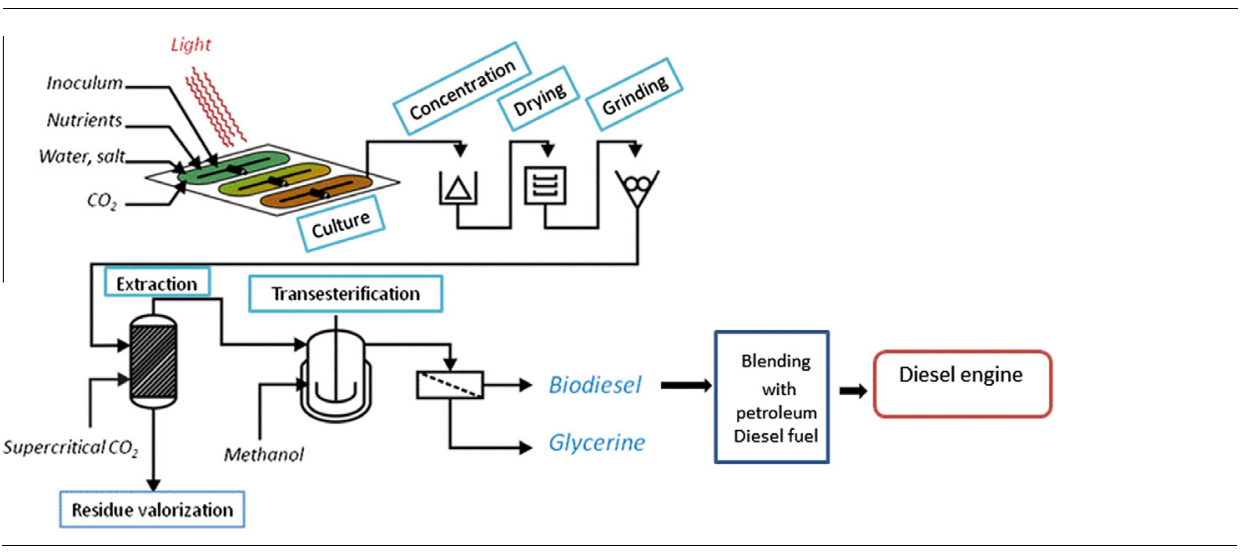

A B S T R A C T

The present article describes the production of oil from autotrophic microalgae grown in raceways in France, and presents the bench test results of a Diesel monocylinder engine with the derived biodiesel (methyl ester).

The cultivation of Nannochloropsis has been performed under nitrogen limitation in order to increase the lipid content of the microalgae. After harvesting, a drying operation has been carried out so as to obtain a dry microalgae powder with controlled water content. Neutral lipids were then recovered using supercritical carbon dioxide extraction technology applied to the dry powder. One hundred kilograms of dry microalgae has been treated leading to about five kilograms of algal oil, free of polar lipids, that has been transesterified with methanol. The fuel obtained has been blended with a standard biofuel-free Diesel fuel (10\% algal fuel/90\% standard Diesel fuel B0) and engine tests have been carried out with the resulting blend (B10). In order to compare with well-known fuels similar engine tests were performed with B0 and with a B10 fuel made of ten percent vegetable oil methyl ester complying with the European 14214 fuel standard (B10 EU-type). The B10 quality was rather close to Diesel fuel except for oxidation stability, which was well below the minimum limit for Diesel fuel. The behavior of the B10 fuel appears to be very similar in terms of combustion efficiency and pollutant emissions to the one of the standard Diesel fuel B0.

\footnotetext{
* Corresponding author.

E-mail address: beatrice.perrier@mpsa.com (B. Perrier).
} 


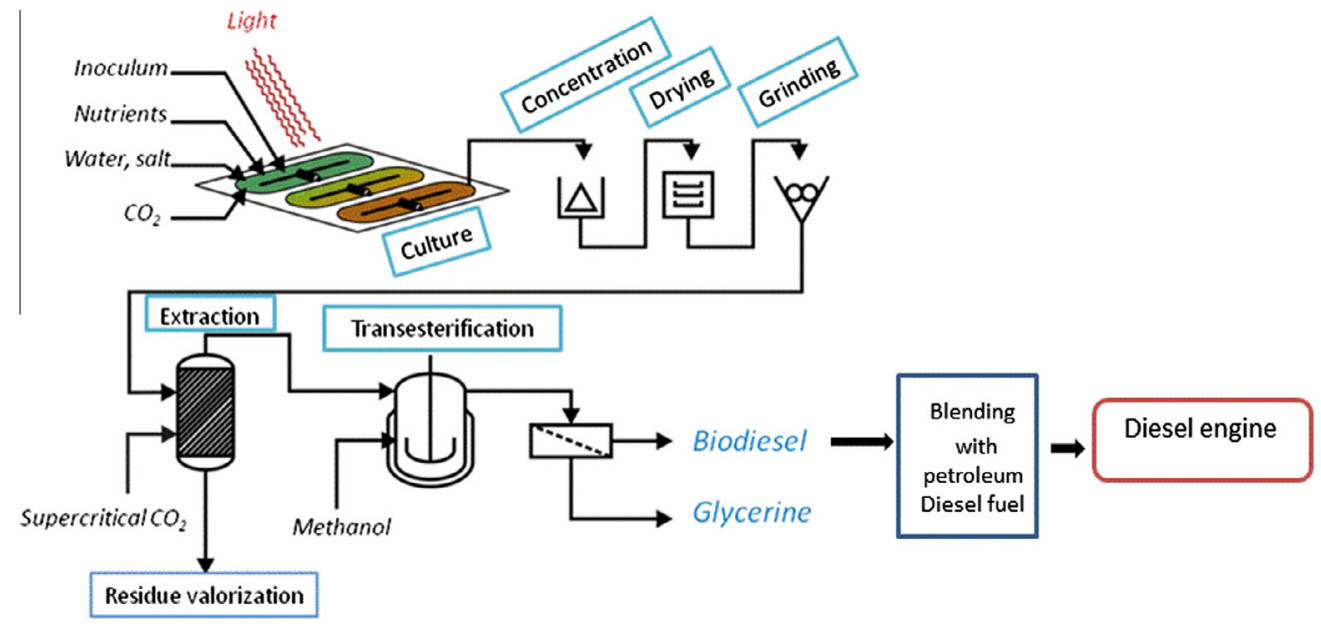

Fig. 1. Successive production steps.

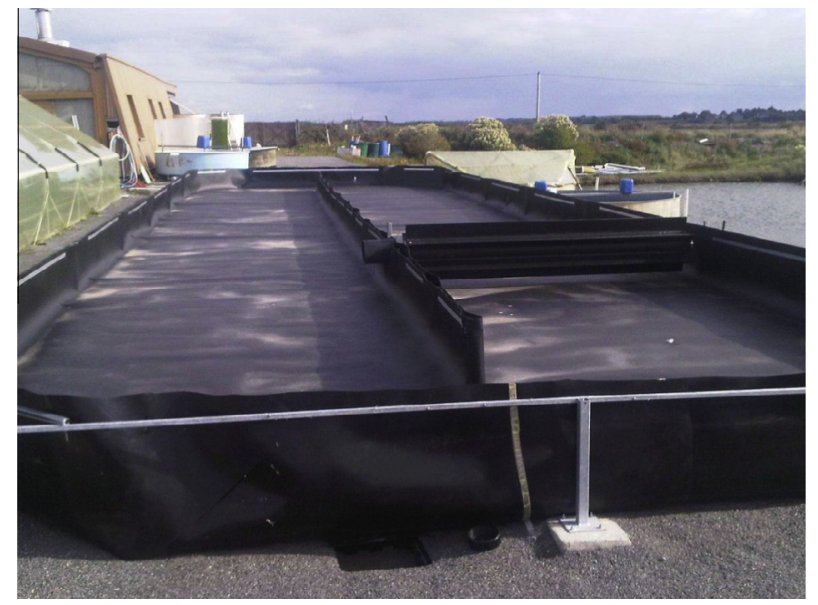

Fig. 2. Alpha Biotech raceways for algal biomass production, Guérande, France.

\section{Introduction}

Europe has a structural deficit in petroleum middle distillates for transport, i.e. jet and Diesel fuels, while there is a gasoline surplus. Therefore, research and development for biofuels has focused on products that could add up to the middle distillate pool. The European biodiesel market has subsequently strongly developed, exploiting food crops (oil seeds) initially on fallow lands in the context of the Common Agricultural Policy. But there is increasing concern about competition with food for land and feedstock.

Therefore, in order to produce fuels that could add up to the middle distillate pool, researchers are targeting other renewable and more sustainable sources, among which microalgae represent an attractive option requiring no agricultural land and potentially

Table 1

Characteristics of the Nannochloropsis species. (Data issued from Van Vooren et al. [8] in flat panel photobioreactor, with constant PFD of $250 \mu \mathrm{mole} / \mathrm{m}^{2} / \mathrm{s}$.)

\begin{tabular}{lll}
\hline & $\begin{array}{l}\text { Optimal growth } \\
\text { conditions }\end{array}$ & $\begin{array}{l}\text { Nitrogen } \\
\text { starvation }\end{array}$ \\
\hline $\begin{array}{c}\text { Total lipid content (\% of dry-weight } \\
\text { concentration) }\end{array}$ & $8-12 \%$ & $50 \%$ \\
TAG content $(\%$ of dry-weight concentration) & $2-3 \%$ & $43 \%$ \\
Biomass productivity $\left(\mathrm{g} / \mathrm{m}^{2} /\right.$ day) & 11 & - \\
Total lipid productivity $\left(\mathrm{g} / \mathrm{m}^{2} /\right.$ day) & $0.9-1.4$ & 4.5 \\
TAG productivity $\left(\mathrm{g} / \mathrm{m}^{2} /\right.$ day $)$ & $0.2-0.3$ & 3.6 \\
\hline
\end{tabular}

offering high productivity rates [1]. Indeed, unicellular photosynthetic organisms (microalgae and cyanobacteria) can use solar photons to convert industrial $\mathrm{CO}_{2}$ into organic molecules that can be turned into biofuel $[1,2]$ or used in the pharmaceutical and food industries [3]. They can be produced in large scale outdoor facilities (closed photobioreactors, or open raceways) in order to improve productivity compared to natural environments [4] and reach lipid yields with a range of magnitude above the best existing agrofuel derived from terrestrial plants. The race for microalgae as a source of renewable Diesel fuel has launched many projects around the world, in the idea of progressing along all the stages of the production process, from the quest of more productive species, improved cultivation set-up, and downstream efficient refining treatments. These improvements target a gain in productivity, and finally a decrease in the cost together with an improvement of the environmental balance [5]. However, the demonstration that the produced lipids could be adapted to a biodiesel use was still rare.

The work described here is one of the very first works of biofuel production from microalgae that include all stages from the microalgae cultivation to the production and characterization of the biofuel, and eventually the use of this biofuel in a Diesel engine.

In the present study, we present the engine tests which have been carried out with a blend containing a methyl ester derived from lipid production by the marine microalgae Nannochloropsis occulata (Eustigmatophyceae). This robust species was selected since it can accumulate large amounts of lipids, is already cultivated at industrial scale, and can adapt to a wide temperature range [6]. The production was carried out in raceways by the Alpha Biotech company from AlgoSource group (Asserac, France)

Table 2

Composition of oil extracts.

\begin{tabular}{|c|c|c|c|c|}
\hline $\begin{array}{l}\text { Extraction } \\
\text { method }\end{array}$ & $\begin{array}{l}\text { Free } \\
\text { fatty } \\
\text { acids } \\
\text { (wt\%) }\end{array}$ & $\begin{array}{l}\text { Triglycerides } \\
\text { (wt\%) }\end{array}$ & $\begin{array}{l}\text { Sterol } \\
\text { (wt\%) }\end{array}$ & $\begin{array}{l}\text { Others (pigments, } \\
\text { unlipidic molecules, } \\
\text { phospholipids) (wt\%) }\end{array}$ \\
\hline Bligh and dyer & 0.71 & 72.13 & 4.58 & 22.58 \\
\hline $\begin{array}{l}\mathrm{SC}-\mathrm{CO}_{2} \\
\quad \text { extraction on } \\
\text { dried biomass } \\
(1 \mathrm{~h})\end{array}$ & 1.14 & 91.36 & 3.41 & 4.09 \\
\hline $\begin{array}{l}\mathrm{SC}-\mathrm{CO}_{2} \\
\quad \text { extraction on } \\
\text { freeze-dried } \\
\text { biomass }(1 \mathrm{~h})\end{array}$ & 0.43 & 91.45 & 5.40 & 2.72 \\
\hline
\end{tabular}




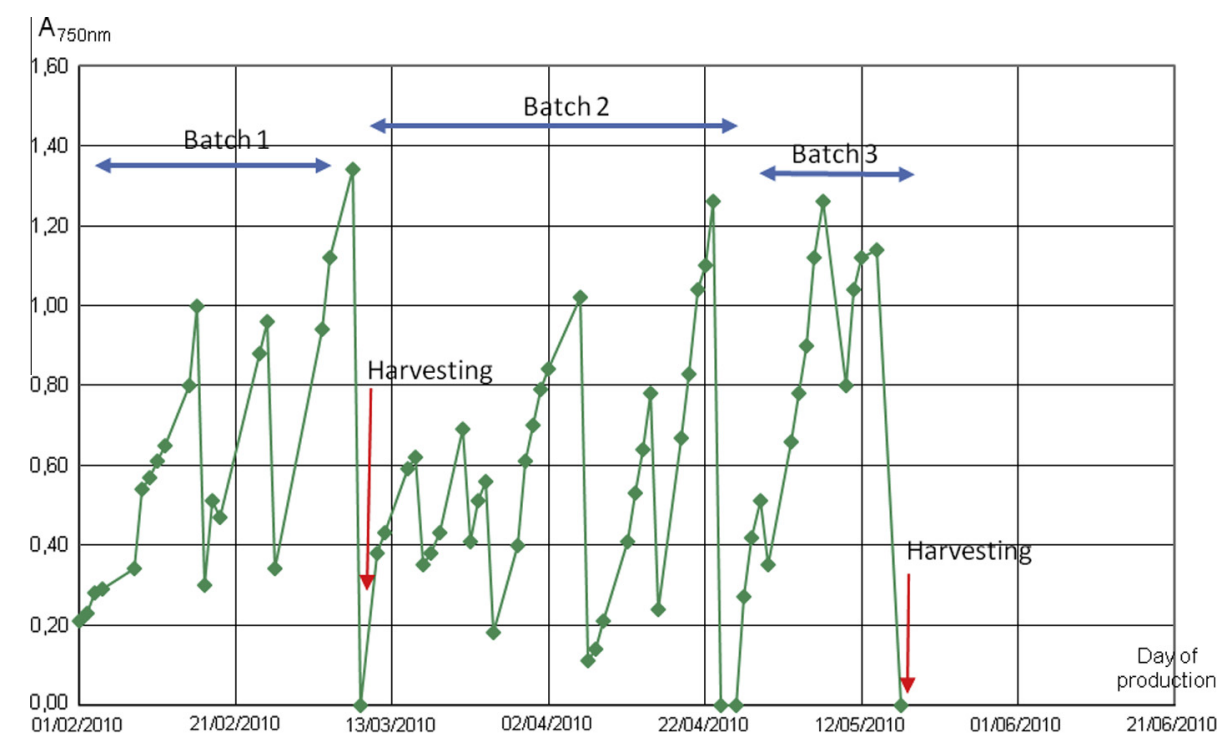

Fig. 3. Example of the monitoring of biomass growth in raceway.

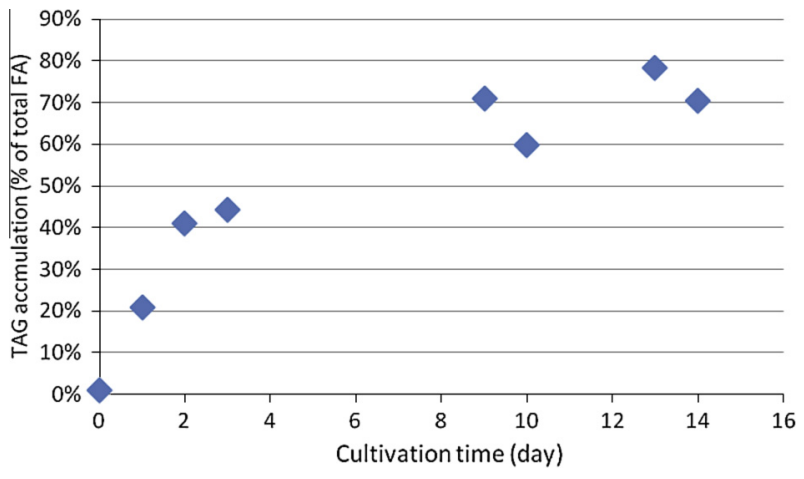

Fig. 4. Example of TAG accumulation in raceway (N-deprivation).

in standard cultivation conditions, along the year (including a large range of temperature and light conditions), submitted to realistic perturbations, including potential external contaminations. Even if the process could largely be optimized, it indicates the quality of the microalgal oil that could be expected from such a process in outdoor conditions.

The work was carried out following a multidisciplinary project (ANR Shamash project) during which lipid rich microalgal species were identified together with cultivation protocol, to trigger the storage of triglycerides, and supercritical extraction techniques have been used to recover selectively the neutral lipids [7].

The project was launched in November 2009 with the cultivation of microalgae. More than one hundred kilograms of dry microalgae have been produced and processed in order to obtain enough fuel to allow exploratory Diesel engine tests after blending with petroleum Diesel fuel.

\section{Experimental section}

In this project, all the different stages of biofuel production have been implemented, from the cultivation of microalgae to the oil extraction and refinery to obtain the methyl ester, which was subsequently blended with petroleum Diesel fuel, and tested in a Diesel engine. Fig. 1 summarizes those different studied steps.

When under metabolic stress (for instance, nitrogen deficiency) algae can accumulate large amounts of lipid, but usually this comes with reduced growth rates. This often leads to grow algae in a two-step process, where a phase of nutrient unlimited growth is followed by a phase of nitrate starvation [8]. So the selected species was first grown in a photobioreactor. Then, a second phase was carried out in open raceways, where a nitrogen deprivency was triggered leading to lipid accumulation.

Algal biomass was harvested, concentrated by centrifugation and dried before the extraction step to separate the oily product (rich fraction in neutral lipids) that was subsequently transesterified to produce methyl ester or "biodiesel". Those steps will be described further.

\subsection{Production of algal biomass and characteristics of algal biomass}

Following an initial production step in photobioreactors (inoculum), the algae was produced in autotrophic conditions using raceways located in Alpha Biotech facilities (Guérande, 200 meters away from the French West Coast, north of Nantes). Raceways were built using supple plastic film, as shown in Fig. 2. Greenhouses were initially to be set up to increase the existing production capacity. However, Alpha Biotech could not obtain a full construction permit so half of the raceways were operated under greenhouses whereas the other half was operated without greenhouses.

Based on different criteria for choosing the best species (growth rate, lipid content typically higher than $30 \%$ of dry matter, resistance to contamination) Nannochloropsis occulata species was selected. This well-known marine algae species is relatively small, and therefore difficult to harvest; however it is less sensitive to climate variations, and is more resistant to potential contaminants than other species. The characteristics of this algae species are indicated in Table 1.

Prior to industrial transposition to Alpha Biotech facilities, a systematic study was conducted in laboratory to optimize protocol for lipids accumulation. Lipids, and especially neutral lipids such as triacylglycerol (TAG), are actually accumulated when algae are deprived of nitrogen under sunlight [1]: these so-called deprivation phases alternate then with growth phases.

Based on previous laboratory results (see Van Vooren et al. [8] for details), a specific protocol adapted to facilities and operating conditions of Alpha Biotech was set. It was based on a succession of a growth stage followed by sudden nitrogen deprivation. 


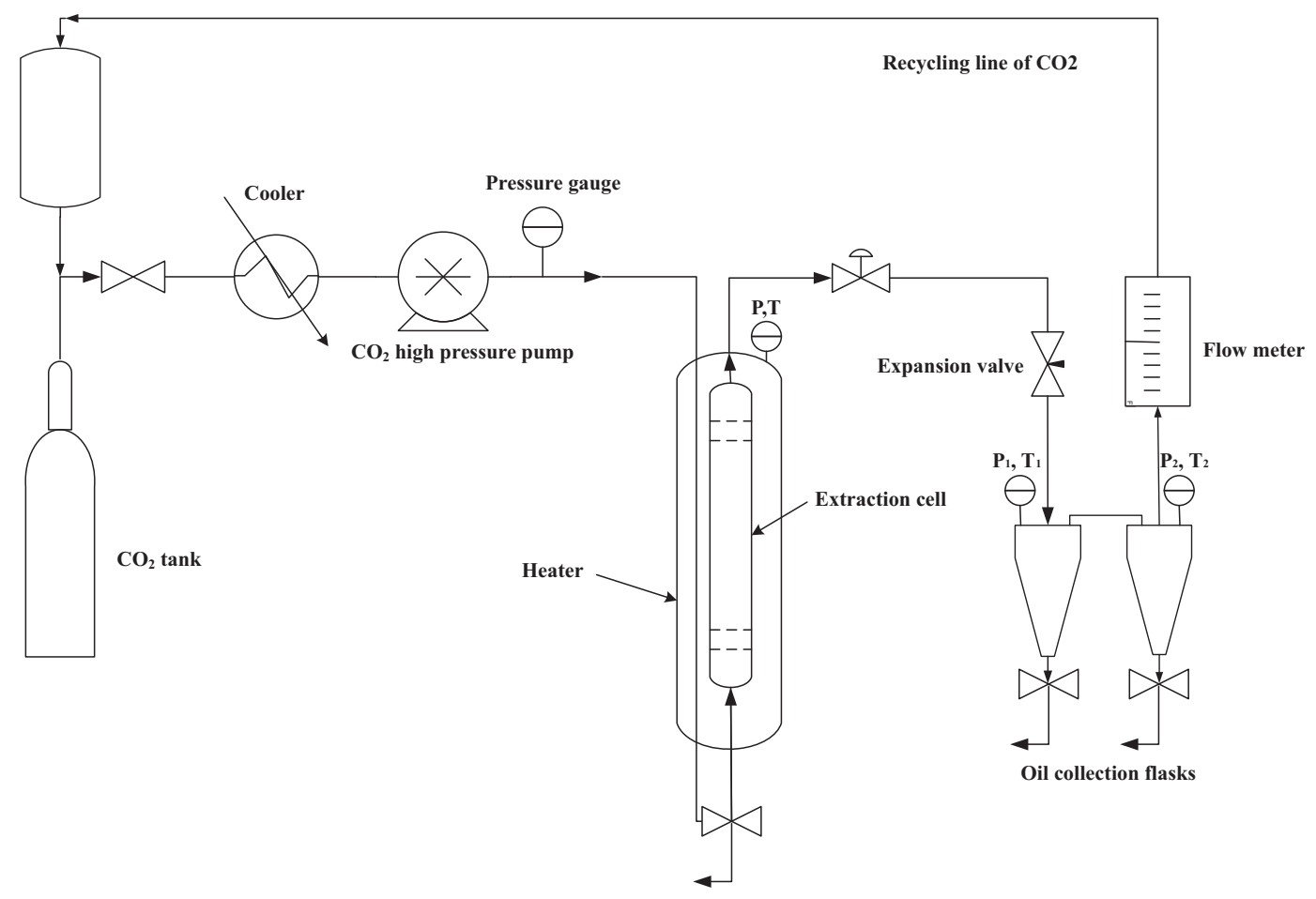

Fig. 5. Classical flowsheet for $\mathrm{SC}-\mathrm{CO}_{2}$ extraction.

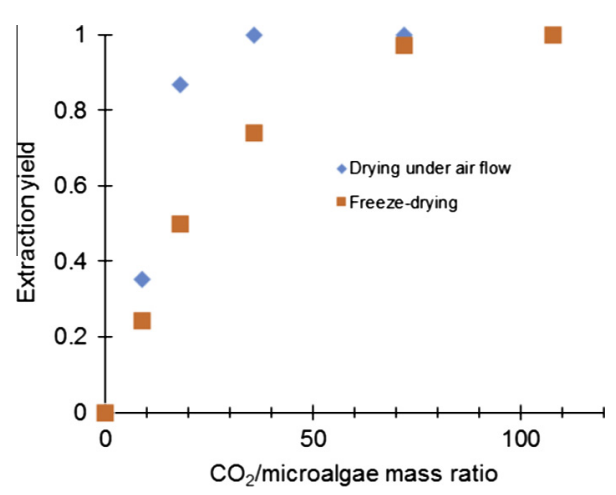

Fig. 6. Extraction curve for a biomass dried under an air flow at $308 \mathrm{~K}$ and for a freeze-dried biomass.

Nitrogen deprivation was obtained by centrifugating the harvest from the growth stage followed by immediate resuspension in a nitrogen free medium. Two parameters were found especially relevant, namely the initial biomass concentration to be set at the beginning of nitrogen deprivation, and the duration of the nitrogen deprivation phase. A low value of initial biomass concentration (typically less than $0.05 \mathrm{~kg} \mathrm{~m}^{-3}$ in raceways) was found necessary to avoid high light attenuations conditions preventing from lipids over-accumulation. The stress phase should last several weeks to let algae accumulate TAG.

Based on those results, a protocol based on nitrogen deprivation was set in Alpha Biotech facilities. An example of successive batch productions is given in Fig. 3. To keep a low biomass concentration and maintain high light conditions on average in the culture, the medium was progressively added for culture dilution. Because Alpha Biotech facilities had no specific equipment to measure instantaneous lipid content, the reaction time was raised to make sure that the actual lipid content was sufficiently high. As shown in Fig. 4, it was found that a duration of about 20 days was necessary to reach an average fatty acid triglyceride content in algae around $20 \% \mathrm{~m} / \mathrm{m}$ of dry matter (fatty acid triglycerides represented $45 \%$ of total lipid content after 5 days, and $70 \%$ after 15 days of production). Highly variable conditions for outdoor culture result into large variation in growth kinetics. Therefore biomass growth on-site was monitored by using absorbance measurement at a wavelength of $750 \mathrm{~nm}$ as a first indicator of biomass concentration. It was observed that sufficient lipids accumulation corresponded to an absorbance value of around 1.2-1.4 (A.U.). This value was then fixed as a set point to trigger biomass harvesting.

Biomass productivity for the whole production period was about $2-3 \mathrm{~g} / \mathrm{m}^{2} /$ day, or $7-11$ tons/hectare/year ( $\left.\mathrm{t} / \mathrm{ha} / \mathrm{y}\right)$. Observed instantaneous productivity was much higher, reaching up to $5 \mathrm{~g} /$ $\mathrm{m}^{2}$ /day or $18 \mathrm{t} / \mathrm{ha} / \mathrm{y}$ under favorable conditions.

Given the small size of the Nannochloropsis species, harvesting is difficult. After cultivation, it was done by centrifugation followed by air drying. The wet paste was then frozen before final extraction which was carried out several weeks after harvesting biomass from the pond.

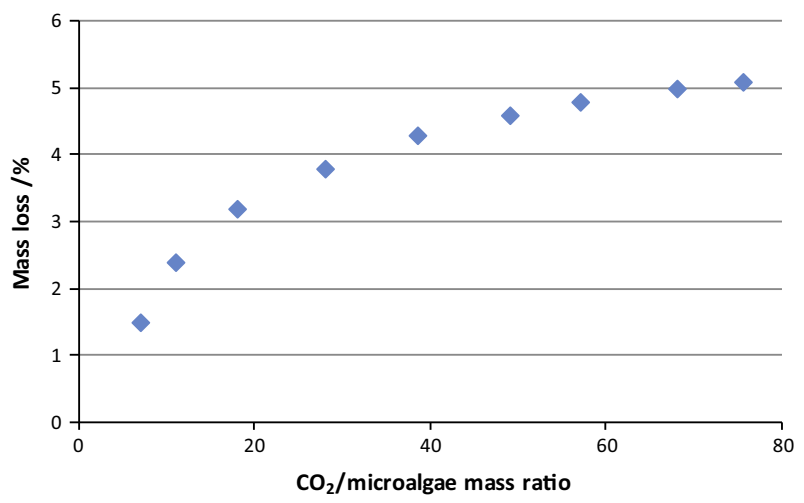

Fig. 7. Extraction curve obtained with a batch of dry biomass of $25 \mathrm{~kg}$ at $85 \mathrm{MPa}$ and $333 \mathrm{~K}$. 
Table 3

Characteristics of the extracted oil.

\begin{tabular}{lll}
\hline Characteristic & Unit & Value \\
\hline Oleic acidity & $(\mathrm{m} / \mathrm{m})$ & $54.24 \%$ \\
Water content (titrimetry, Karl Fischer method) & $\mathrm{g} / 100 \mathrm{~g}$ & 0.84 \\
Phosphorus (P) content & $\mathrm{mg} / \mathrm{kg}$ & 4 \\
Sodium (Na) content & $\mathrm{mg} / \mathrm{kg}$ & 49.2 \\
Potassium (K) content & $\mathrm{mg} / \mathrm{kg}$ & $<15$
\end{tabular}

\subsection{Oil extraction}

Traditionally, vegetable oil is extracted either mechanically by crushing, or chemically with n-hexane, a petroleum derivative, as a solvent to obtain higher yields. An alternative to liquid organic solvent extraction was tested in our project. In order to avoid the use of an organic solvent, generally toxic, flammable and with low selectivity, an extraction with supercritical carbon dioxide $\left(\mathrm{SC} \mathrm{CO}_{2}\right)$ has been implemented. This method of extraction has already been applied to microalgae and seaweeds [9].

The SC- $\mathrm{CO}_{2}$ extraction technology is well-known today, industrialized for several applications for about thirty years and considered as a green process since $\mathrm{CO}_{2}$ is a Generally Recognized As Safe (GRAS) solvent (not toxic nor flammable). The critical temperature of $\mathrm{CO}_{2}$ is low $(304.21 \mathrm{~K})$ compared to other solvents. Thermolabile compounds present in the extract and the residue are therefore preserved for further valorization. Many other advantages can be listed on the use of $\mathrm{SC}-\mathrm{CO}_{2}$ for the extraction of triglycerides for biofuel applications, and probably the main one is the selectivity

Table 4

Fatty acids in the oil produced from microalgae.

\begin{tabular}{|c|c|c|}
\hline Usual name & Carbons - unsaturated bonds & Content (\%) \\
\hline Caproïc acid & $6: 0$ & 0.1 \\
\hline Caprylic acid & $8: 0$ & 0.1 \\
\hline Capric acid & $10: 0$ & 0.1 \\
\hline Lauric acid & $12: 0$ & 0.5 \\
\hline Tridecanoic acid & $13: 0$ & 0.1 \\
\hline Myristic acid & $14: 0$ & 6.3 \\
\hline Myristoleic acid & $14: 1$ & 0.3 \\
\hline Pentadecanoic acid & $15: 0$ & 0.6 \\
\hline Palmitic acid & $16: 0$ & 22.3 \\
\hline \multirow[t]{2}{*}{ Palmitoleic acid } & $16: 1$ & 32.9 \\
\hline & $16: 2$ & 0.5 \\
\hline \multirow[t]{2}{*}{ Hiragonic acid } & $16: 3$ & 0.4 \\
\hline & $16: 4$ & 0.4 \\
\hline \multirow[t]{2}{*}{ Margaric acid } & $17: 0$ & 0.3 \\
\hline & $17: 1$ & 0.3 \\
\hline Stearic acid & $18: 0$ & 0.9 \\
\hline Oleic acid & $18: 1$ & 6.6 \\
\hline Linoleic acid & $18: 2(n-6)$ & 1.1 \\
\hline Gama linolenic acid & $18: 3(n-6)$ & 0.3 \\
\hline Linolelinic acid & $18: 3(n-3)$ & 0.1 \\
\hline Stéradonic acid & $18: 4(n-3)$ & 0.1 \\
\hline Arachidic acid & $20: 0$ & 0.1 \\
\hline \multirow[t]{2}{*}{ Gondoïc acid } & $20: 1$ & 0.1 \\
\hline & $20: 2(n-6)$ & 0.1 \\
\hline \multirow[t]{2}{*}{ Arachidonic acid } & $20: 4(n-6)$ & 1.6 \\
\hline & $20: 4(n-3)$ & 0.3 \\
\hline EPA & $20: 5(n-3)$ & 16.1 \\
\hline Behenic acid & $22: 0$ & 0.1 \\
\hline Erucic acid & $22: 1$ & $<0.1$ \\
\hline DPA & $22: 5(n-3)$ & 0.1 \\
\hline DHA & $22: 6(n-3)$ & 0.2 \\
\hline Lignoceric acid & $24: 0$ & 0.2 \\
\hline \multicolumn{2}{|c|}{ Non identified identified } & 6.8 \\
\hline \multicolumn{2}{|c|}{ Total Saturated fatty acids } & 31.7 \\
\hline \multicolumn{2}{|c|}{ Total Monounsaturated fatty acids } & 40.2 \\
\hline \multicolumn{2}{|c|}{ Total Polyunsatured fatty acids } & 21.3 \\
\hline \multicolumn{2}{|c|}{ of which: $(n-3)$} & 16.9 \\
\hline \multicolumn{2}{|l|}{ of which: $(n-6)$} & 3.1 \\
\hline
\end{tabular}

of this solvent for neutral lipids. Indeed, $\mathrm{SC}-\mathrm{CO}_{2}$ is a quite good solvent for non-polar molecules such as triglycerides, but it does not solubilize phospholipids [9]. This feature is very useful for biodiesel applications because it eliminates the degumming unit operation.

After depressurization, $\mathrm{CO}_{2}$ becomes gaseous and is then spontaneously separated from the extracted phase and residue which are completely free of toxic solvent traces. This enables therefore a direct valorization of both extracts and residues without any additional processing. On an industrial scale, $\mathrm{SC}-\mathrm{CO}_{2}$ is recycled. The recycling rate can be up to $98 \%$. In summary, the use of $\mathrm{SC}-\mathrm{CO}_{2}$ instead of organic solvents would provide a cleaner and more compact extraction process since operations of degumming and separation of extract from solvent are avoided.

Nevertheless, as for extraction using liquid organic solvents, supercritical extraction is performed on a dry biomass. Since the drying step is energy intensive when applied to microalgal suspension (with a water content of about $60-80 \mathrm{wt} \%$ after centrifugation), it may constitute an economic lock for further development of these processes at industrial scale. Recent works [7] have demonstrated that $\mathrm{SC}-\mathrm{CO}_{2}$ extraction can be performed on a microalgal biomass with water content reaching up to $25 \mathrm{wt} \%$. In that case, part of the water is recovered in the extract. Extracts are then composed of neutral lipids and of water [7].

A SC- $-\mathrm{CO}_{2}$ extraction is classically carried out as follows (see Fig. 5). The autoclave is initially filled with the dry microalgae powder and heated until the desired temperature is reached. Liquid $\mathrm{CO}_{2}$ (purity of $99.7 \%$ from Air Liquide Méditerranée, France) is cooled by a cryogenic bath at $277 \mathrm{~K}$, filtered and pumped into the extractor until the working pressure is reached. The pressure is controlled by a pressure gauge. Then the expansion valve is opened and a flow of $\mathrm{CO}_{2}$ goes through the microalgae powder at constant pressure, temperature and flow rate during predefined durations corresponding to the extraction times. After passing through the extractor, $\mathrm{CO}_{2}$ is expanded through an expansion valve. $\mathrm{CO}_{2}$ becomes gaseous, and extracted compounds are collected in a collecting vessel. The $\mathrm{CO}_{2}$ flow rate is measured by a flow meter placed at the end of the extraction line.

Prior to extraction at an industrial scale (at $\mathrm{NateCO}_{2}$ facilities, Germany) to obtain a sufficient volume of lipids in view of engine fuel production, extraction experiments were carried out at two different scales.

First experiments were performed at lab-scale on batches of about $10 \mathrm{~g}$ of dry biomass. The influence of the drying method on the extraction kinetics has been studied. The biomass has been dried using either a drying under an air flow at $308 \mathrm{~K}$ or a freezedrying in order to obtain a biomass with a water content of $5 \mathrm{wt} \%$. Extraction experiments at lab-scale have been carried out at $40 \mathrm{MPa}, 333 \mathrm{~K}$, and with a $\mathrm{CO}_{2}$ flowrate of $0.4 \mathrm{~kg} \cdot \mathrm{h}^{-1}$ using a set-up provided by Separex S.A. (Champigneulles, France). After the grinding step, a fine fraction of powder (mean diameter comprised between 160 and $350 \mu \mathrm{m}$ ) has been isolated. The complete extraction curves obtained with this fraction are represented on Fig. 6. The extraction is significantly more rapid for a biomass dried under an air flow. Indeed, for a mass ratio $\mathrm{CO}_{2}$ /biomass of 36 , the mass loss is of $30 \mathrm{wt} \%$ for the sample dried under an air flow while it is of $15 \mathrm{wt} \%$ for a freeze-dried biomass. From the shape of the extraction curve of the freeze-dried sample, the mass transfer limitation by diffusion is obvious. Since freeze-drying treatment preserves cell integrity, the oil mass transfer by diffusion is then more limited. Thus, the extractions have been stopped after two different durations. Final mass loss was about $30.2 \mathrm{wt} \%$ (for a mass ratio $\mathrm{CO}_{2}$ /biomass of 72 ) for the sample dried under an air flow and of $19.8 \mathrm{wt} \%$ (for a mass ratio $\mathrm{CO}_{2} /$ biomass of 108 ) for the freezedried sample. The lipid classes in the extract have been determined by Chromatography Iatroscan (Iatroscan New MK 5 from Iatron). 
Table 2 presents the composition of the extracts obtained after one hour of supercritical extraction from the sample dried under air flow and from the freeze-dried sample. For comparison, a Bligh and Dyer extraction has been performed and the extract composition has been also determined. It is worth noting that the supercritical extracts are composed of more than $90 \mathrm{wt} \%$ of triglycerides and that there are no phospholipids in the extracts; such a composition suits well the targeted application which is biodiesel production. It has to be noted that at laboratory scale, microalgae powders and extracts were stored in a freezer at $253 \mathrm{~K}$ under an inert atmosphere of $\mathrm{CO}_{2}$.

All the results obtained at lab-scale, including lipidic profiles of extracts, are further detailed elsewhere [7].

Extraction was then performed at larger scales, on batches varying from 2 to $15 \mathrm{~kg}$ under different pressures and temperatures. Results have been detailed elsewhere [7].

Then, using the facilities of $\mathrm{Nateco}_{2}$ (Wolnzach, Germany) extraction was performed on $100 \mathrm{~kg}$ of biomass dried under air flow. The biomass was ground with a hammer mill. The mean diameter of the powder was about $0.5 \mathrm{~mm}$. Since the granulometry was higher than for lab-scale experiments and in order to avoid long duration experiments, those large scale experiments were performed at higher pressure conditions. Indeed, the solubility of solutes in the supercritical phase increases when the pressure increases, resulting into a more rapid extraction. Four batches of $25 \mathrm{~kg}$ were treated in an autoclave of $50 \mathrm{l}$ under $85 \mathrm{MPa}$, at $333 \mathrm{~K}$ and with a $\mathrm{CO}_{2}$ flowrate of $300 \mathrm{~kg} \mathrm{~h}^{-1}$.

Fig. 7 shows the extraction curve representing the variation of mass loss in the autoclave versus the $\mathrm{CO}_{2} /$ microalgae mass ratio obtained for one of the four batches. From the shape of the curve, it can be seen that the extraction is limited by diffusion. Despite the long extraction duration (more than 6 hours, final mass ratio $\mathrm{CO}_{2} /$ biomass of 75.5) and the high pressure conditions the extraction is not complete (the plateau corresponding to the end of extraction was not reached). Following the four extractions, slightly more than $5.2 \mathrm{~kg}$ of oil have been recovered corresponding then to a yield of $5.2 \%$.

The obtained extracts were analysed. Tables 3 and 4 show the acidity rate, the water content, the phosphorus content and the composition of extracts.

A main point has to be highlighted: the strong acidity of the oils extracted at large scale illustrates that these extracted oils contain large amounts of free fatty acids (FFA) in comparison with the amount of triglycerides. It has to be reminded that the extracted oil at lab-scale contained more than $90 \mathrm{wt} \%$ of triglycerides. The high value of FFA's content in extracts obtained at larger scale suggests that triglycerides were probably degraded during storage at ambient conditions. It can be then concluded that it is

Table 5

Analytical results - characteristics of biodiesel.

\begin{tabular}{|c|c|c|c|c|}
\hline Characteristics & & Method & Specifications & Results \\
\hline Density at $15^{\circ} \mathrm{C}$ & $\mathrm{kg} / \mathrm{m}^{-3}$ & $\begin{array}{l}\text { EN ISO } \\
12185\end{array}$ & $860-900$ & $892.1 \pm 0.4$ \\
\hline Viscosity at $40^{\circ} \mathrm{C}$ & $\mathrm{mm}^{2} / \mathrm{s}$ & EN ISO 3104 & $3.50-5.00$ & $5.08 \pm 0.04$ \\
\hline Water content & $\%(\mathrm{~m} / \mathrm{m})$ & $\begin{array}{l}\text { EN ISO } \\
12937\end{array}$ & $<500 \mathrm{ppm}$ & $0.082 \pm 0.014$ \\
\hline Cloud point & ${ }^{\circ} \mathrm{C}$ & EN 23015 & & $-6 \pm 2.83$ \\
\hline $\begin{array}{l}\text { Cold Filter Plugging } \\
\text { Point (CFPP) }\end{array}$ & ${ }^{\circ} \mathrm{C}$ & EN 116 & & $-6 \pm 2.26$ \\
\hline $\begin{array}{l}\text { Oxidation } \\
\text { stability }\end{array}$ & $\mathrm{h}$ & $\begin{array}{l}\text { EN } 15751 \\
\text { (Rancimat) }\end{array}$ & $\geqslant 8$ & $0.8 \pm 0.4$ \\
\hline Ester content & $\%(\mathrm{~m} / \mathrm{m})$ & $\begin{array}{l}\text { EN } 14103: \\
2011\end{array}$ & $\geqslant 96.5$ & $89.4 \pm 2.94$ \\
\hline
\end{tabular}

recommended to store microalgae biomass at $253 \mathrm{~K}$ and under inert atmosphere (nitrogen).

As oil extraction by supercritical carbon dioxide is a selective process, this is here interesting to compare those results to the composition of lipids contained in Nannochloropsis, as investigated in Van Vooren et al. [7] for the same strain grown under nitrogen limitations. Nannochloropsis, as a marine microalgal species, is enriched in unsaturated fatty acids $(\omega-3, \omega-6)$ which are mainly contained in membrane constituents. Nannochloropsis neutral lipids and especially TAG are in the opposite poorly unsaturated (less than rapeseed, soybean or sunflower oil). As a consequence, nitrogen starvation which results in a drastically increase in TAG content also decreases the unsaturation degree of total lipids contained in biomass. This is then in favor of biodiesel application, where saturated FA have to be preferred for a higher freezing point and oxidative stability. As shown by Van Vooren et al. [8], under normal physiological culture conditions (growth phase), total lipids which accounted for 8-12\% of biomass was mainly composed of $\mathrm{C} 16: 1 \mathrm{n}-7, \mathrm{C} 20: 5 \mathrm{n}-3, \mathrm{C} 16: 0$ and $\mathrm{C} 14: 0$ (resulting in an unsaturation degree between 1.8 and 2.1). In nitrogen starvation, TAG which accounted for around $30-45 \%$ of biomass (around $70-85 \%$ of total lipids) mainly contained $\mathrm{C} 16: 0$ and $\mathrm{C} 16: 1 \mathrm{n}-7$ which accounted each for $45 \%$ of the TAG content (leading to a lower unsaturation degree around 0.5).

Regarding those results, the analysis of oil extracted by supercritical carbon (Table 4) tends thus to confirm that lipids recovered by this process were mainly from the TAG part, but the extract was also certainly composed of non TAG fatty acids, and more specifically, of membrane fatty acids because of the relative high concentration of unsaturated fatty acids obtained such as C20:5n-3 (16\% of oil extract). Supercritical carbon extraction being known to mainly extract neutral lipids, this surprising result emphasized certainly a potential degradation of intracellular lipids and maybe cells partial lysis. This hypothesis tends here also to be confirmed by free acids found in the extract which indicate cells lysis. As a result, oil extracted was enriched in unsaturated fatty acids issued from a partial degradation of cell membrane (whose natural content in C20:5n-3 only is around 28\%). These so-called omega 3 fatty acids are highly valorized as food complements for their benefits on human health (prevention of heart problems, Alzheimer's disease, etc).

This result illustrates here the necessity to control storage conditions between biomass culture and treatment. In our study, biomass was centrifuged and the wet-paste was then frozen before final extraction, which could occur for practical reason several weeks after biomass harvesting from the pond. This conditioning was maybe not sufficient to stop cell lysis or at least lipase enzymes activity, leading to a partial biomass or lipids degradation. Regarding our result, it should certainly have been necessary to add an inert gas $\left(\mathrm{N}_{2}\right)$ during storage to prevent from lipids oxidation (but this was not tested).

\subsection{Biodiesel production}

By analogy with vegetable fatty acids that are converted into alkyl esters, the oil that had been extracted by supercritical $\mathrm{CO}_{2}$ from algal biomass, was esterified into alkyl esters compatible with Diesel fuel. However, given the high content in free acids from the

Table 6

Elementary analysis of the product - obtained by spectroscopy (wavelength dispersive X-Ray fluorescence and inductively coupled plasma atomic emission).

\begin{tabular}{lllll}
\hline Content & {$[\mathrm{Cl}]$} & {$[\mathrm{S}]$} & {$[\mathrm{Br}]$} & {$[\mathrm{I}]$} \\
\hline $\mathrm{mg} / \mathrm{kg}$ & $80-110$ & $12-20$ & $8-12$ & $7-9$ \\
\hline
\end{tabular}


Table 7

Maximum levels for sulfur, phosphorus and metals in EN 14214

\begin{tabular}{lll}
\hline Characteristics & Units & Specifications EN 14214 \\
\hline Sulfur content & $\mathrm{mg} / \mathrm{kg}$ & $\leqslant 10$ \\
Group I $(\mathrm{Na}+\mathrm{K})$ metals & $\mathrm{mg} / \mathrm{kg}$ & $\leqslant 5$ \\
Group II $(\mathrm{Ca}+\mathrm{Mg})$ metals & $\mathrm{mg} / \mathrm{kg}$ & $\leqslant 5$ \\
Phosphorus & $\mathrm{mg} / \mathrm{kg}$ & $\leqslant 4$ \\
\hline
\end{tabular}

microalgae, oil transesterification conducted by conventional methods (homogeneous catalyst in a basic medium) was not feasible.

As a matter of fact, when a base homogeneous catalyst is used, if the oil contains high free fatty acids, those acids react with the catalyst to produce emulsified soap that inhibit biodiesel production. This saponification phenomenon is avoided when an acid catalyst is applied but it has a smaller catalytic effect on the transesterification (lower yield).

A two-step process, acid-catalyzed esterification followed by base-catalyzed transesterification was employed for the production of biodiesel from algal oil to resolve the problems of saponification phenomenon by first removing FFA thanks to acid esterification before conducting a base transesterification.

The acid pretreatment process was optimized to reduce the FFA content of algal oil below $1 \%$ for maximum biodiesel production and the reaction parameters for the base transesterification with methanol using base catalyst were also optimized.

The reactor was filled with algal oil and heated to remove the moisture content. The reaction mixture of concentrated catalyst in appropriate volume of methanol was separately heated at $40{ }^{\circ} \mathrm{C}$ and then added to the reactor. The mixture was stirred up and refluxed for the required reaction time to complete the esterification $(180 \mathrm{~min})$. The progress of the reaction was routinely monitored by measuring the acid value and FFA and the samples were withdrawn at pre-determined time intervals to calculate acid value. After acid catalyzed esterification, the final reaction mixture was poured into a separating apparatus. The upper layer was collected and purified using distilled water and measured to calculate the biodiesel yield. The lower layer was separated, washed, and centrifuged to remove excess alcohol, acid catalyst and impurities. Then the mixture was dried and used for further processing into biodiesel by base catalyzed transesterification: the pretreated mixture was poured into the reactor and heated. The base catalyst was first dissolved into methanol and then added to the mixture. The reaction mixture was stirred at relaxed temperature. The samples were withdrawn from the reaction mixture at pre-determined time intervals to measure the yield of methyl ester (ME). After $90 \mathrm{~min}$, the reaction mixture was poured into a separating funnel and allowed to separate into two layers. The upper phase consists of ME and the lower layer contains glycerol with other impurities. The lower layer was discarded. The upper ME layer was collected and further purified by washing with hot distilled water. Residual water was removed and the ME layer was dried then filtred.

\subsection{Biodiesel fuel analysis}

Thus, $5 \mathrm{l}$ of limpid methyl ester from algae oil were produced and delivered to PSA Peugeot Citroën that conducted several analyses in its fuel laboratory.

According to Gaseous chromatography, $89.4 \%$ of the product was detected as fatty acid methyl esters.

The analysis indicated high contents in polyunsaturated esters with more than four double bonds: C20:5n3 (ester derived from Eicosapentaenoate acid, EPA), C22:5 (from Docosapentaenoic acid, DPA) and C22:6n3 (from Docosahexaenoic acid, DHA) together account for $17.7 \%$ of the product.

The remainder of the product includes unconverted triglycerides $(2.72 \% \mathrm{~m} / \mathrm{m})$ and monoglycerides $(0.27 \% \mathrm{~m} / \mathrm{m})$.

The characteristics of the biodiesel that were measured are listed in Table 5. This analysis indicates high water content (above the norm), high viscosity, marginally superior to the upper limit, and overall a poor oxidation stability. (In order to save a sufficient amount of product to blend in Diesel fuel for engine tests the volume used for fuel analysis was limited. As a result, all the regulatory characteristics could not be analyzed: in particular the cetane number was not measured).

Complementary analyses were conducted to determine the content in sulfur and metals that are detrimental to engine functioning. Results are indicated in Table 6. Contents in sulfur, chloride, and bromure and iodine are above the maximum levels that are fixed in the European norm for biodiesel (EN14214), see Table 7. The content in chloride is especially high, as could be expected from plants grown in salt water.

Based on the HFRR test the lubricity of the fuel was correct: 171 micrometers, well below the maximum limit of 460 micrometers.

\subsection{Engine test}

Ten percent of this algal fuel was blended with ninety percent of standard biofuel-free Diesel fuel (referred as B0): the resulting blend is refered as B10 Shamash fuel.

In order to compare with well-known fuels similar engine tests were performed with B0 and with a B10 fuel made of ten percent vegetable oil methyl ester complying with the European EN14214 fuel standard (B10 EU-type).

The B10 quality was rather close to Diesel fuel except for oxidation stability, which was well below the minimum limit for Diesel fuel (see Table 8).

The lubricity of B10 fuel was satisfying (HFRR test indicated a value of 171 micrometers, below the maximum limit of 460

Table 8

Properties and characteristics of the three different studied fuels (B0, B10 Shamash fuel, B10 EU type).

\begin{tabular}{|c|c|c|c|c|c|}
\hline Property & Norms & Units & B0 & B10 Shamash fuel - this work & B10 EU type (vegetable oil methyl ester) \\
\hline Cetane index & NF EN ISO 5165 & & 52.6 & 52.4 & 52.4 \\
\hline Density at $15^{\circ} \mathrm{C}$ & EN ISO 12185 & $\mathrm{~kg} / \mathrm{m}^{3}$ & $834.8 \pm 0.4$ & $840.4 \pm 0.4$ & 835 \\
\hline Viscosity at $40^{\circ} \mathrm{C}$ & EN ISO 3104 & $\mathrm{~mm}^{2} / \mathrm{s}$ & $2.5420 \pm 0.02$ & $2.7230 \pm 0.02$ & 2.53 \\
\hline Cloud point & EN 23015 & ${ }^{\circ} \mathrm{C}$ & $-23 \pm 2.83$ & $-21 \pm 2.83$ & -21 \\
\hline CFFP & EN 116 & ${ }^{\circ} \mathrm{C}$ & $-22 \pm 4.84$ & $-21 \pm 3.35$ & -26 \\
\hline HHV & NFM 07030 & $\mathrm{~mJ} / \mathrm{kg}$ & 45.720 & 45.105 & 45.52 \\
\hline LHV & NFM 07030 & $\mathrm{~mJ} / \mathrm{kg}$ & 42.870 & 42.265 & 42.74 \\
\hline Carbon & ASTM D 5291 & $\% \mathrm{~m} / \mathrm{m}$ & 86.7 & 85.4 & 86.1 \\
\hline Hydrogen & ASTM D 5291 & $\% \mathrm{~m} / \mathrm{m}$ & 13.42 & 13.37 & 13.1 \\
\hline Oxygen & MO238LA2008 & $\% \mathrm{~m} / \mathrm{m}$ & $<0.2$ & 1.23 & 0.7 \\
\hline Oxidation stability & EN 15751 (Rancimat) & $\mathrm{h}$ & $45.8 \pm 6.4$ & $4.7 \pm 0.9$ & $>40$ \\
\hline
\end{tabular}




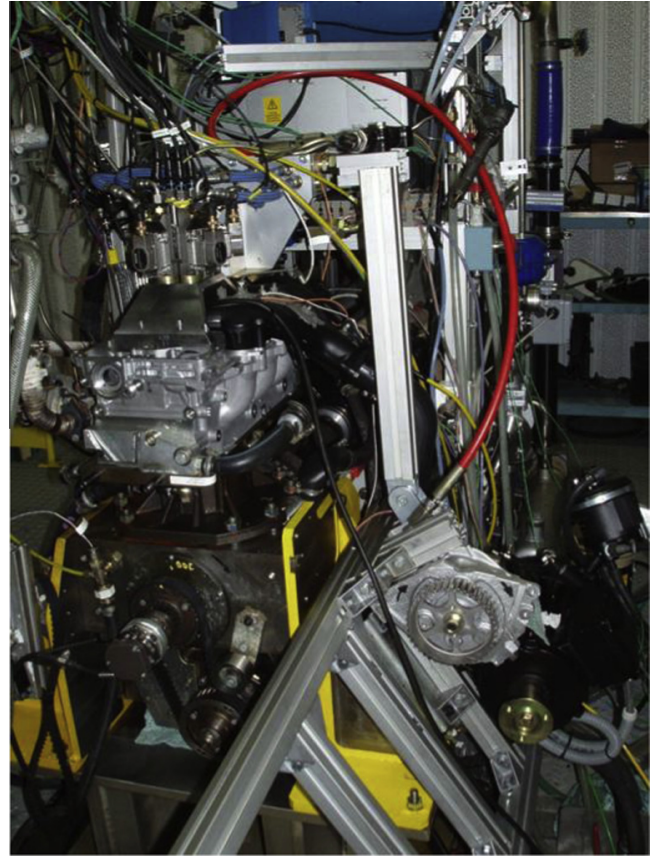

Fig. 8. Photography of the engine used for the tests.

micrometers for European Diesel fuel, test method EN ISO 121561).

The engine was a Diesel single cylinder high pressure direct injection (HDi) 0.51 turbocharged engine based on a DW10 engine (see Fig. 8). The engine characteristics are given in Table 9.

The focus was on combustion performances and pollutant exhaust emissions.

The engine tests were performed at PSA research center at Vélizy, France. They were conducted at iso-heat release rates. Exhaust Gas Recirculation (EGR) sweep was done at a speed rate of $1500 \mathrm{rpm}$ and an effective pressure of 6 bars. Tests were done successively with the three fuels that are mentioned above.

The variation of combustion efficiency has been plotted as a function of $\mathrm{NO}_{x}$ emissions for the three different fuels, at a speed rate of $1500 \mathrm{rpm}$ and an effective pressure of 6 bar (Fig. 9). In both conditions, the behavior of the B10 Shamash fuel is similar to the one of the pure Diesel fuel B0.

Based on PSA experience, the results for the B10 Shamash fuel were in the acceptable range.

Pollutant emissions were also studied (see Fig. 10). Particulates, $\mathrm{HC}$ and $\mathrm{CO}$ emissions are comparable to those observed for B0 Fuel.

Note: At low $\mathrm{NO}_{x}$ emissions, i.e. high EGR rate, combustion speed is lower; which results in higher pollutant emissions.

The variation of the richness of the different fuels (which is the Fuel to Air ratio, $\mathrm{F} / \mathrm{A}$ ratio) as a function of $\mathrm{NO}_{x}$ emissions at a speed rate of $1500 \mathrm{rpm}$ and an effective pressure of 6 bar is shown on Fig. 11: the relative positions of the different fuels in terms of fuel

Table 9

Engine characteristics.

\begin{tabular}{ll}
\hline Engine & PSA DW10, direct injection Diesel \\
\hline Type & Monocylinder, turbocharged \\
Displacement volume & $500 \mathrm{~cm}^{3}$ \\
Bore/stroke & $85 / 88 \mathrm{~mm}$ \\
Compression ratio & 16 to 1 \\
Injection system & Delphi DDS DFI1.5 \\
\hline
\end{tabular}

richness explain why B10 Shamash behavior in terms of pollutants was so close to B0 fuel.

Overall, the combustion behavior of the B10 Shamash fuel was comparable to Diesel fuel without any biofuel (B0), and rather satisfactory.

However, engine tests were stopped by injection problems: within 15 min injectors stopped functioning. The injectors were subsequently analysed by the equipment manufacturer Delphi. It appeared that the valve within the injector was blocked because of a brown substance, and the holes of the injector nozzle were plugged by dark deposits (see Fig. 12a). The presence of several scratches on the valve stem indicated that particles had gone through the injector (see Fig. 12b). After cleaning (ultrasounds) the injector was restored to normal functioning.

From these tests it was concluded that the Shamash biodiesel from algae had been degraded because of its extremely low oxidation stability, leading to some organic polymers that blocked the injector system. The algal biodiesel was most probably partially degraded during its storage.

\subsection{Life cycle analysis (LCA)}

A Life Cycle Analysis simulation was performed, on the basis of the process used to produce Nannochloroposis [10]. It indicated that the system is not yet competitive with rapeseed oil (or methyl ester), in line with other studies [5]. This is actually not suprising since, in such a research project with innovative (not yet mature) technology the system is not designed to minimize energy consumption, which strongly affects the overall energy balance. The energy demand is especially high for biomass harvesting, and oil extraction.

More specifically, the LCA pointed out that improving the energy balance is clearly the key priority to make microalgal cultivation sustainable and to reduce its greenhouse gas (GHG) emissions. LCA results are mainly dependent on biomass productivity. To reach a GHG balance comparable to rapeseed algal biomass productivity must reach $10 \mathrm{~g} / \mathrm{m}^{2} /$ day. However, whatever their productivity, algae are better placed in terms of water eutrophisation and land occupation [10].

Since a large fraction of environmental impacts and especially GHG emissions do not occur directly at the production facility but stem from the production of the electricity required for producing, harvesting and transforming algae, the source of electricity plays a key role. We therefore studied a scenario where up to $45 \%$ of electricity was produced by a local renewable source ("Ecomix" scenario) whose production is assumed to be integrated to the

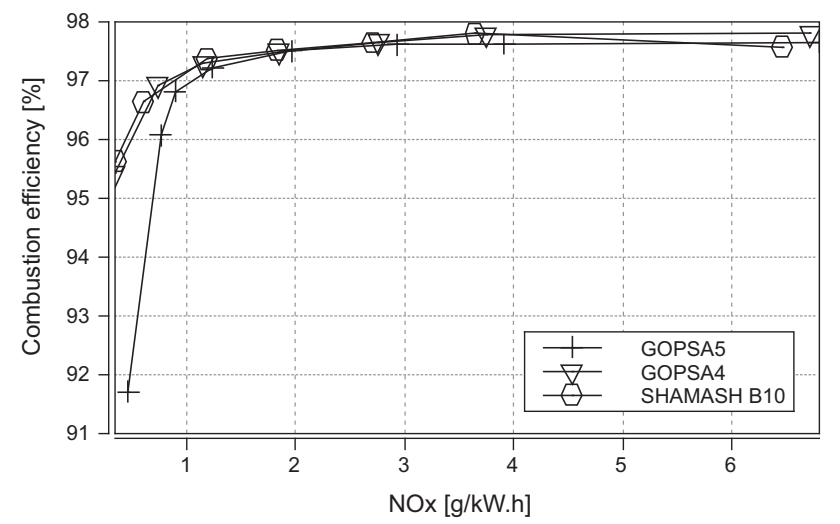

Fig. 9. Variation of combustion efficiency as a function of $\mathrm{NO}_{x}$ emissions for the three different fuels, at a speed rate of $1500 \mathrm{rpm}$ and an effective pressure of 6 bar. 


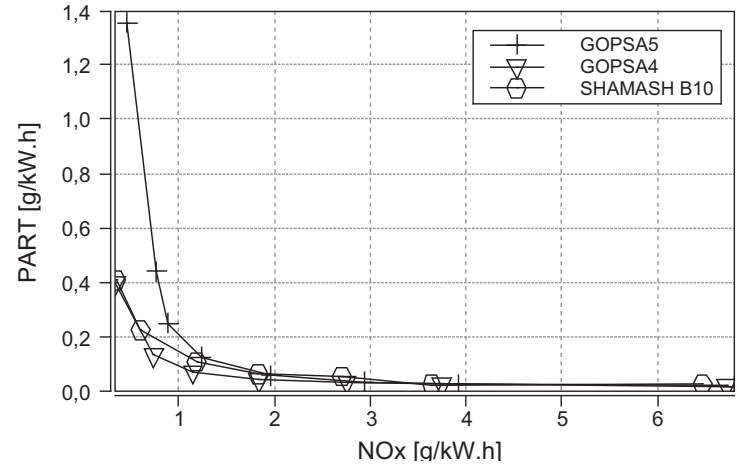

(a)

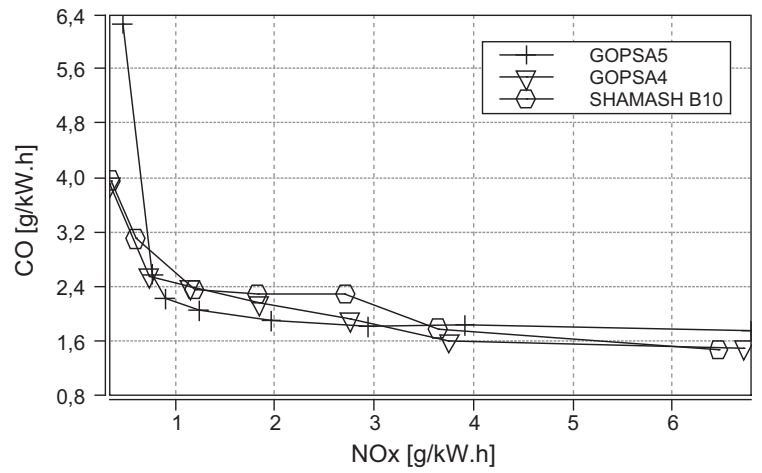

(b)

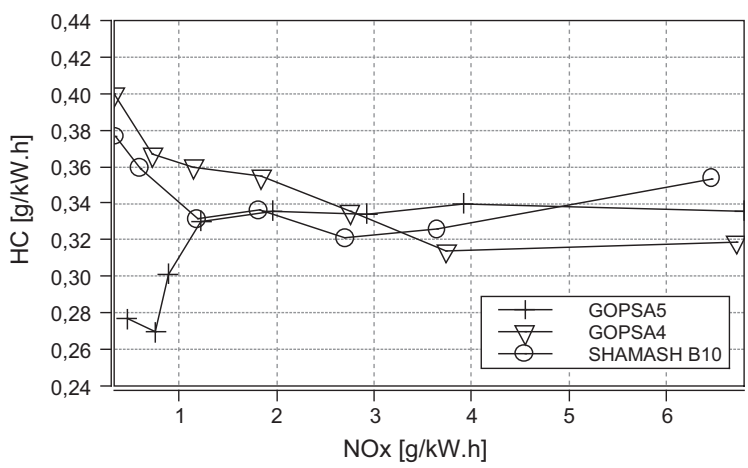

(c)

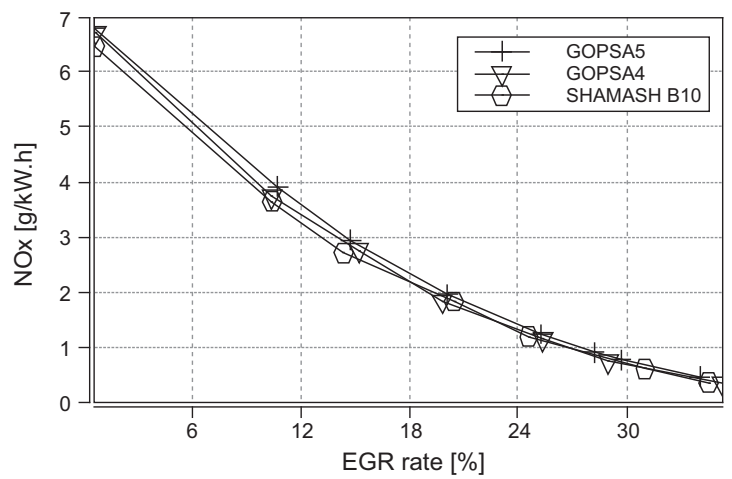

(d) NOx emissions vs EGR rate

Fig. 10. Variation of particulates emissions (Fig. 10a), HC emissions (Fig. 10b), and $\mathrm{CO}$ emissions (Fig. 10c), as a function of $\mathrm{NO}_{x}$ emissions for the three different fuels, at a speed rate of $1500 \mathrm{rpm}$ and an effective pressure of 6 bar. Fig. 10d represents $\mathrm{NO}_{x}$ emissions as a function of the EGR rate.

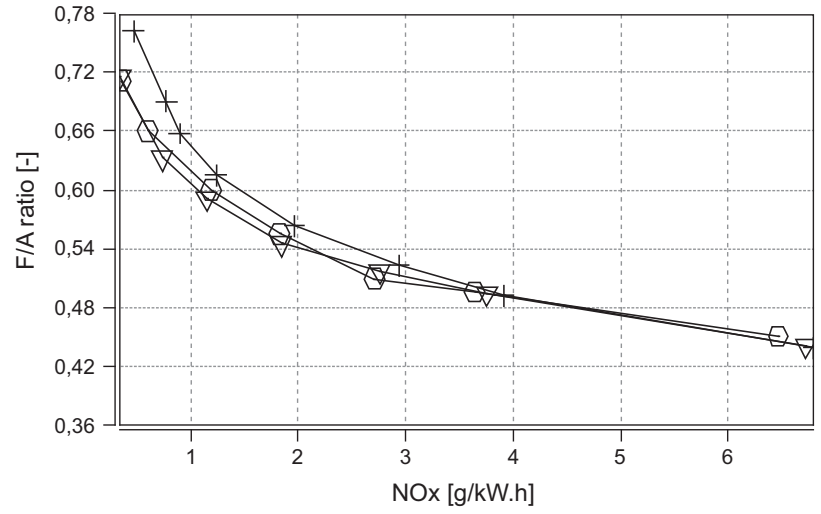

Fig. 11. Richness of the different fuels at a speed rate of $1500 \mathrm{rpm}$ and an effective pressure of 6 bar.

(a)

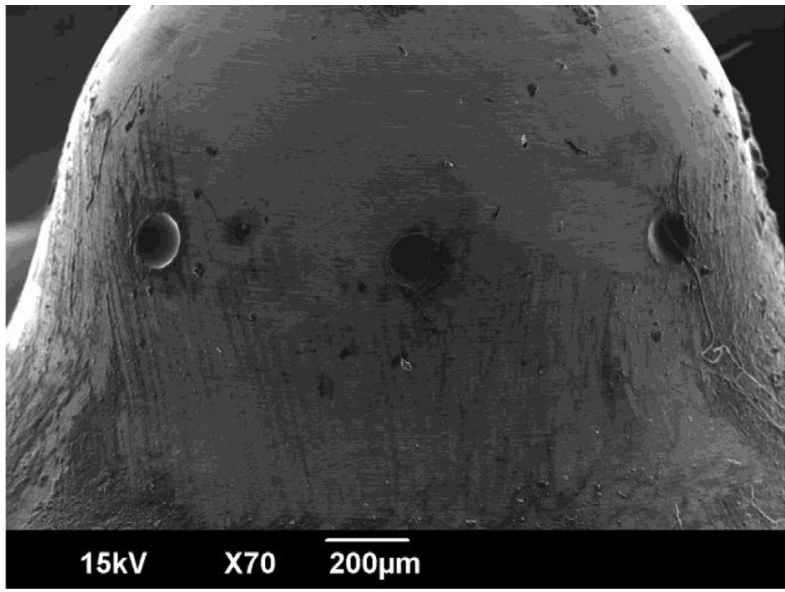

(b)

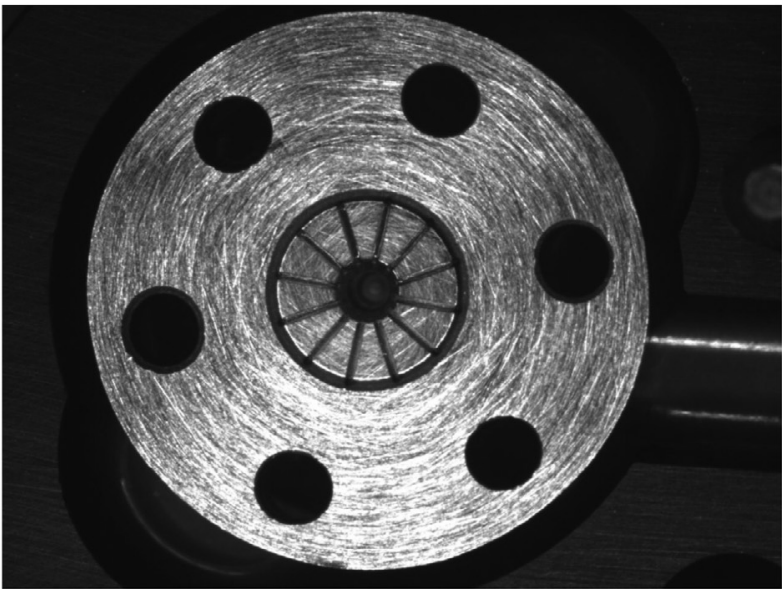

Fig. 12. Photos of injector parts after engine tests with Shamash fuel.

raceways setup. We considered a source of renewable electricity such as windmill implemented between the raceways in order not to affect the microalgal productivity. Then we compare the improvements in terms of GHG emissions from technological breakthroughs resulting in higher microalgal productivity or biomass concentration. It turns out that with conventional European energetic mix ("Euromix" scenario), a productivity of more than $10 \mathrm{~g} / \mathrm{m}^{2} / \mathrm{d}$ is required to reach similar climate change impact than for rapeseed whereas a productivity of $5 \mathrm{~g} / \mathrm{m}^{2} / \mathrm{d}$ is enough when local renewable electricity is produced (see Fig. 13). 


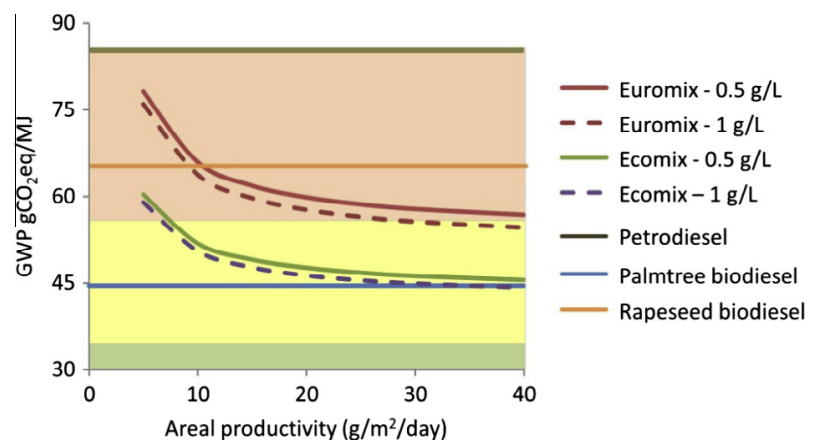

Fig. 13. Impact of productivity on GHG emission in comparison to diesel, palmtree or rapeseed biodiesel (four scenarri are considered for the microalgal production: 0.5 or $1 \mathrm{~g} / \mathrm{l}$ with a european mix of electricity - Euromix, or with a fraction of renewable energy - Ecomix).

\section{Conclusion}

This 4-year project has succeeded to produce methyl ester from algae oil in autotrophic conditions in Western Europe, and to test it on an automotive Diesel engine bench.

This field experiment has highlighted the actual challenges that appear much more significant than literature tends to indicate: algae sensitivity to climatic conditions (including unexpected events like the Xynthia storm) and cultivation difficulties; harvesting which is delicate and energy consuming; storage which is necessary in practice but could lead to partial degradation of biomass and extracted oil; extraction that appears complex and challenging to get acceptable yields at the pilot level; and the impact on product quality for subsequent transformations (transesterification). For all of those steps going from the laboratory, where optimized oil-producing protocols can for instance be easily set up, to the pilot stage, is an additional challenge. It involves scaling-up of outdoor processes under uncontrolled and highly varying conditions.
In addition, our complete analysis of the algal biodiesel emphasized that the quality of the microalgae biofuel must be improved. Whereas the fuel properties related to combustion (heating value, density, cetane number lubricity) were satisfying, the poor oxidation stability resulted in aggressive behavior towards the engine injection system. Therefore, further treatments during the production process would have been required in our case: treatment of the algal oil, and more probably further steps of fuel refining, notably hydrotreating (instead of transesterification) to get rid of triple unsaturated components.

It may be possible to avoid these additional refining steps by working directly on the quality of the extracted oil. This could be obtained by selecting a strain with fatty acids profiles more suitable for biodiesel application or by improving both production and extraction steps, including storage phase in-between.

\section{Acknowledgements}

The authors kindly acknowledge the financial support of Airbus Group which sponsored the project together with PSA Peugeot Citroën.

\section{References}

[1] Chisti Y. Biotechnol Adv 2007;25:294-306.

[2] Wijffels RH, Barbosa MJ. Science 2010;329:796-9.

[3] Milledge JJ. Rev Environ Sci Biotechnol 2010;10(1):31-41.

[4] Campbell PK, Beer T, Batten D. Bioresour Technol 2011;102(1):50-6.

[5] Lardon L, Hélias A, Sialve B, Steyer JP, Bernard O. Environ Sci Technol 2009;43(17):6475-81.

[6] Biondi et al. 2012.

[7] Crampon C, Mouahid A, Toudji S-A, Lépine O, Badens E. J Surcrit Fluids 2013;79:337-44

[8] Van Vooren G, Le Grand F, Legrand J, Cuiné S, Peltier G, Pruvost J. Bioresour Technol 2012:124:421-32.

[9] Crampon C, Boutin O, Badens E. Industr Eng Chem Res 2011;50(15):8941-53.

[10] Collet P, Lardon L, Hélias A, Bricout S, Lombaert-Valot I, Perrier B, et al. Renew. Energy 2014;71:525-33. 